\title{
Corrigendum: Towards Mass Spectrometry Imaging in the Metabolomics Scale: Increasing Metabolic Coverage Through Multiple On-Tissue Chemical Modifications
}

\author{
Maria Emilia Dueñas, Evan A. Larson and Young Jin Lee* \\ Department of Chemistry, lowa State University, Ames, IA, United States
}

Keywords: mass spectrometry imaging, metabolomics, on-tissue derivatization, high-spatial resolution, maize, single cell

\section{A Corrigendum on}

Toward Mass Spectrometry Imaging in the Metabolomics Scale: Increasing Metabolic Coverage Through Multiple On-Tissue Chemical Modifications

\section{OPEN ACCESS}

Approved by:

Frontiers in Plant Science, Frontiers Media SA, Switzerland

*Correspondence:

Young Jin Lee yilee@iastate.edu

Specialty section:

This article was submitted to Plant Metabolism and

Chemodiversity,

a section of the journal

Frontiers in Plant Science

Received: 07 August 2019

Accepted: 08 August 2019 Published: 11 September 2019

Citation:

Dueñas ME, Larson EA and Lee YJ

(2019) Corrigendum: Towards Mass Spectrometry Imaging in the

Metabolomics Scale: Increasing Metabolic Coverage Through Multiple On-Tissue Chemical Modifications.

Front. Plant Sci. 10:1079.

doi: 10.3389/fpls.2019.01079
By Dueñas ME, Larson EA and Lee YJ (2019) Front. Plant Sci. 10:860. doi: 10.3389/fpls.2019.00860

In the original article, there was a mistake in the legend for Figure $\mathbf{2}$ and Figure $\mathbf{3}$ as published. The legends for Figures $\mathbf{2}$ and $\mathbf{3}$ are switched. The corrected legend appears below.

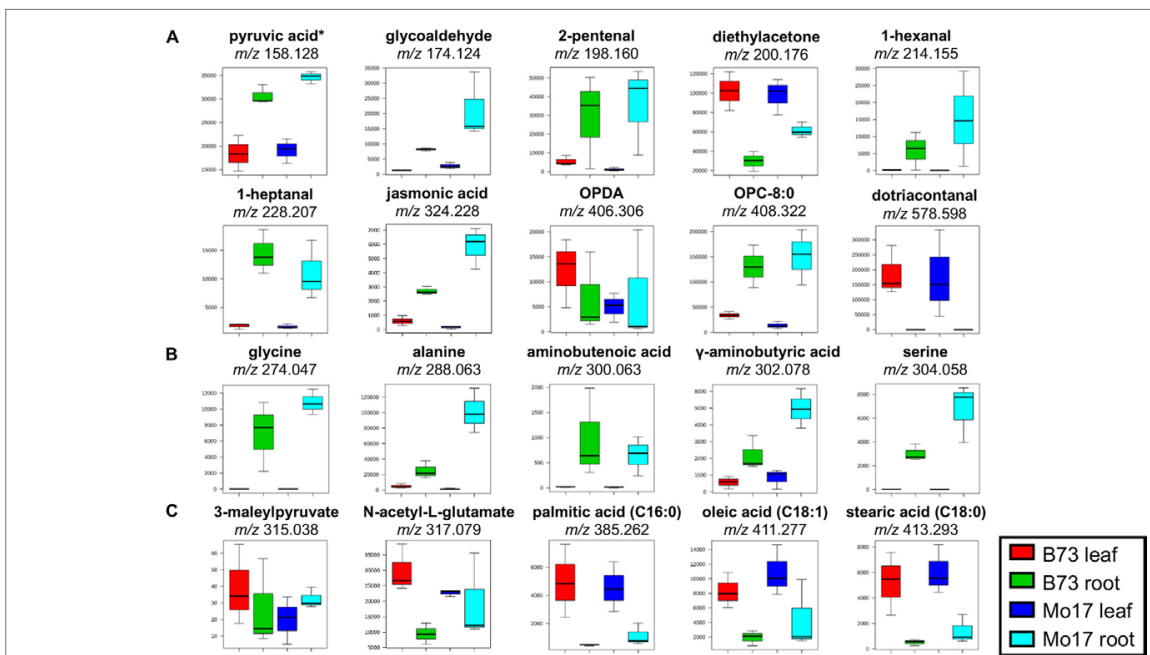

FIGURE 2 | Box and whisker plots for selected metabolites derivatized with (A) GT, (B) CA, and (C) 2-PA. *Pyruvic acid is a fragment with CO2-loss as discussed in the text. Only one example is shown out of all the possible metabolites; see Supplementary Table S1A for other possible metabolites. All data is obtained in positive mode. 


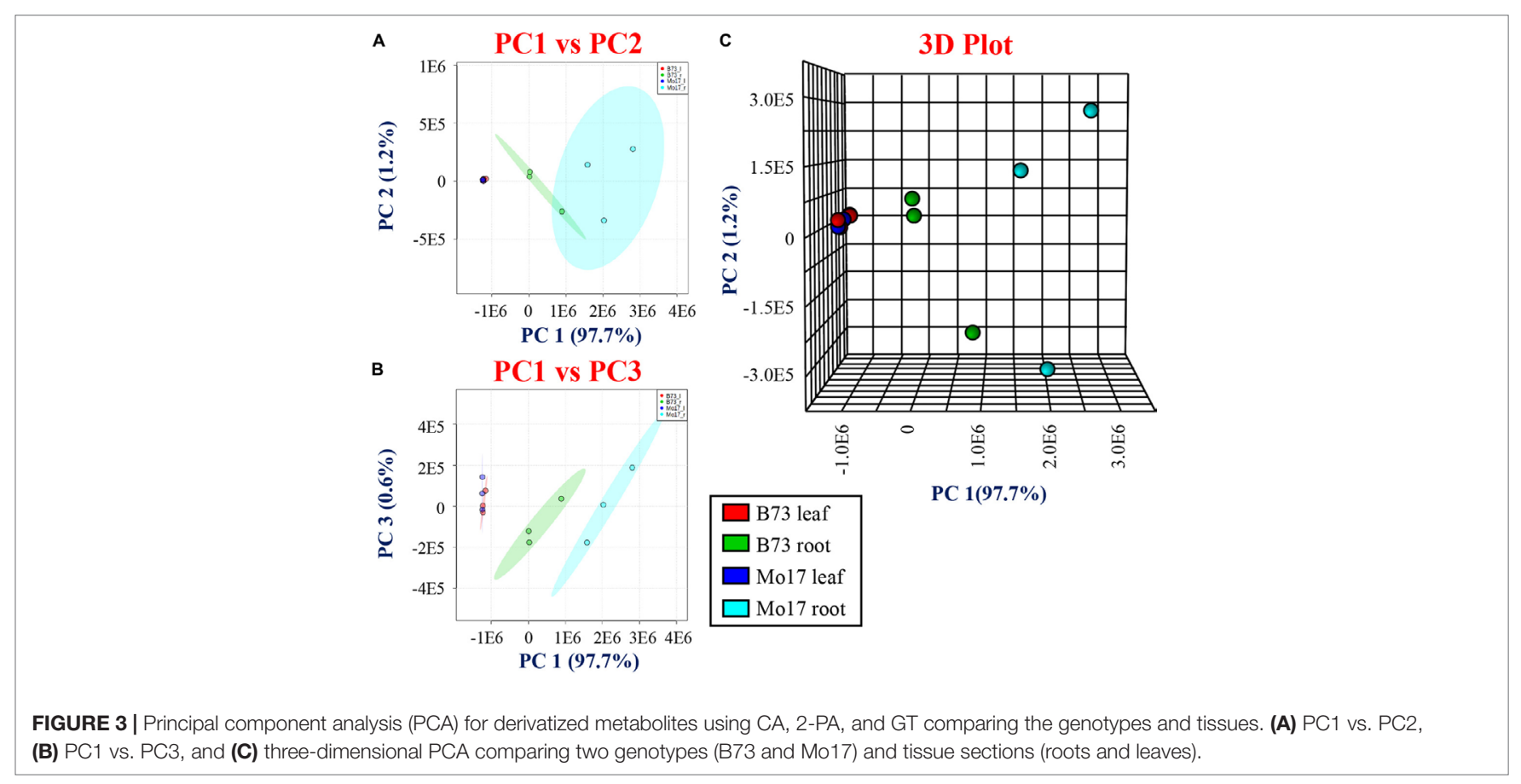

The authors apologize for this error and state that this does not change the scientific conclusions of the article in any way. The original article has been updated.
Copyright $\odot 2019$ Dueñas, Larson and Lee. This is an open-access article distributed under the terms of the Creative Commons Attribution License (CC BY). The use, distribution or reproduction in other forums is permitted, provided the original author(s) and the copyright owner(s) are credited and that the original publication in this journal is cited, in accordance with accepted academic practice. No use, distribution or reproduction is permitted which does not comply with these terms. 